\title{
Growth and mortality of Norway spruce and European beech in monospecific and mixed-species stands under natural episodic and experimentally extended drought. Results of the KROOF throughfall exclusion experiment
}

\author{
H. Pretzsch ${ }^{1} \cdot$ T. Grams ${ }^{2} \cdot$ K. H. Häberle ${ }^{2} \cdot$ K. Pritsch ${ }^{3} \cdot$ T. Bauerle $^{4} \cdot$ T. Rötzer $^{1}$
}

Received: 14 November 2019 / Accepted: 19 March 2020 / Published online: 11 April 2020

(c) The Author(s) 2020

\begin{abstract}
Key message Under severe drought, growth of Norway spruce suffered much more than European beech. Norway spruce benefited from growing in the environment of beech, and both species acclimated slightly to 5 years of experimentally extended drought.

Abstract Recent studies show that the detrimental effects of drought on stand growth are mitigated when the stand contains mixed tree species. We analysed the growth responses of Norway spruce and European beech to episodic and experimentally extended drought in intra- and inter-specific mature stands. We used annual diameter growth records dating back to 1998 to determine the impact of the natural episodic drought in 2003 and 2015. To analyse extended drought, spruce and beech trees were exposed to extreme drought under automatic throughfall exclusion roofs from 2014 to 2018 . The growth of spruce in an inter-specific environment with beech was $20-50 \%$ less affected by natural episodic drought compared with an intraspecific constellation. When beech grew in an inter-specific environment, it was by $23 \%$ more affected by drought compared to intra-specific conditions, but seemed to recover faster. The induced drought from 2014 to 2018 resulted in a strong growth reduction in the first year particularly for spruce, followed by a slight acclimation to the dry conditions. Beech acclimated and recovered faster than spruce across all growing conditions, while spruce only acclimatized faster in the environment of beech. Both species showed a higher mortality under induced drought compared with the controls; for spruce, the mortality rate was fivefold higher compared to the long-term mortality. The long-term moderate-growth stabilization and the growth increase after the 5-year exposure to drought suggest a gradual acclimation to drought by beech. The resistance and acclimation to drought of spruce when growing in mixture should be considered when designing resource efficient and productive mixed conifer-broadleaved stands for future climates.
\end{abstract}

Keywords Drought $\cdot$ Picea abies $\cdot$ Fagus sylvatica $\cdot$ Mortality $\cdot$ Mixed forests

Communicated by Heckathorn.

H. Pretzsch

H.Pretzsch@1rz.tum.de

1 Chair for Forest Growth and Yield Science, TU München, Hans-Carl-von-Carlowitz-Platz 2, 85354 Freising, Germany

2 Ecophysiology of Plants, TU München, Hans-Carl-von-Carlowitz-Platz 2, 85354 Freising, Germany

3 German Research Center for Environmental Health, Institute of Biochemical Plant Pathology, Helmholtz Zentrum München, Ingolstädter Landstraße 1, 85764 Neuherberg, Germany

4 School of Integrative Plant Science, Cornell University, Ithaca 14853, USA

\section{Introduction}

Severe drought events in Central Europe in 1976, 2003, and 2015 triggered multiple studies on the effects of episodic drought on the growth and mortality of forest tree species (Allen et al. 2015; Bréda et al. 2006; Ciais et al. 2005). The findings suggest that tree species cultivated at or beyond the border of their natural range, such as Norway spruce (Picea abies [L.] Karst) and European larch (Larix decidua Mill), in Central Europe show severe growth reduction and mortality (Kölling et al. 2009; Lévesque et al. 2013) during extreme drought events. To mitigate the effects of drought on tree productivity and survival, silviculture practices aim 
to select better acclimated species and provenances (Atzmon et al. 2004; Arend et al. 2011; Zang et al. 2011). Scots pine (Pinus silvestris L.) and sessile oak (Quercus petraea L.), for instance, are less susceptible to drought (Walentowski et al. 2007; Zang et al. 2011, 2012) than Norway spruce and becoming more suitable for forestry in Central Europe under climate change scenarios that predict future warm and dry conditions. Possible silvicultural practices in view of climate change include down regulating stand density (D'Amato et al. 2013; Sohn et al. 2016), modified thinning practices (Gebhardt et al. 2014; Pretzsch et al. 2018; Rodríguez-Calcerrada et al. 2011), and the promotion of mixed tree species plantings (Ammer 2017). The latter's efficacy, however, has yet to be assessed for drought mitigation (Grossiord 2018).

Most current knowledge on tree responses to drought is derived from the analyses of episodic drought events like those in 1976, 2003, and 2015. However, the effects of extended drought periods on tree growth, as expected under future climate scenarios, are still unknown. It is currently thought that the ability of trees to acclimate to drought is underestimated (Lapenis et al. 2005; Reich et al. 2016). Forests may acclimate to extended drought by physiological, morphological, and allometric adjustment at the tree level (Aasamaa et al. 2004; Pretzsch et al. 2013; Schuldt et al. 2016), and by density reduction, structural, and species compositional changes at the stand level (Lapenis et al. 2005).

Here, we analysed and compared the growth responses of Norway spruce (Picea abies [L.] Karst.) and European beech (Fagus sylvatica $[L$.$] ) to natural episodic and experimentally$ extended drought in mature monospecific and mixed-species stands of Norway spruce and European beech in the Kranzberg Forest. This study utilized the throughfall exclusion experiment KROOF in the Kranzberg Forest (Pretzsch et al. 2014; Tomasella et al. 2018; Hesse et al. 2019) and additional long-term tree measurements nearby (Pretzsch et al. 1998). To better understand the long-term effects of drought on tree growth in intra- and inter-specific environments, we concentrated on the following questions and hypotheses:

Q1: How do species react to natural drought events (represented by the years 2003 and 2015) in intra- versus interspecific environments?

H1: The growth adjustments of Norway spruce and European beech do not differ and are equal in intra-specific and inter-specific environments.

Q2: How do species respond to extended (5-year-long) experimentally induced drought? What drives adjustments in growth with a focus on intra- versus inter-specific environments?

$\mathrm{H} 2$ : The growth of Norway spruce is equal to European beech; intra-specific responses do not differ from inter-specific responses; and all trees in a stand react similarly.

Q3: How does the extended (5-year-long) experimentally induced drought affect the tree mortality?
H3: Tree mortality does not differ between the treatment and control plots.

We also further discuss the ecological and practical silvicultural implications of growth responses to episodic and extended drought.

\section{Materials and methods}

\section{Description of the study sites}

Kranzberg Forest (longitude: $11^{\circ} 39^{\prime} 42^{\prime \prime}$ E, latitude: $48^{\circ}$ $25^{\prime} 12^{\prime \prime} \mathrm{N}$, altitude $490 \mathrm{~m}$ a.s.l) is located in Southern Germany, approximately $35 \mathrm{~km}$ Northeast of Munich. Average annual precipitation is $750-800 \mathrm{~mm} \mathrm{yr}^{-1}$ with $460-500 \mathrm{~mm}$ during the growing season (May-September). The average annual air temperature is $7.8^{\circ} \mathrm{C}$ and $13.8^{\circ} \mathrm{C}$ on a seasonal basis. At the site, monospecific and mixed-species stands of Norway spruce and European beech stock grow on luvisol originating from loess over Tertiary sediments that provide a high nutrient and water supply (Göttlein et al. 2012; Pretzsch et al. 1998). Depending on soil depth, the water holding capacity for plant available water ranges between 17 and $28 \%$ of volumetric soil water content, while soil $\mathrm{pH}_{\mathrm{H} 2 \mathrm{O}}$ varied between 4.1 and 5.1 .

We characterized the water supply for each year by calculating the index of de Martonne (1926) ( $\mathrm{M}=$ precipitation/ (temperature +10)) on the basis of the precipitation (in $\mathrm{mm}$ ) and temperature (in ${ }^{\circ} \mathrm{C}$ ) for the whole year $\left(M_{\mathrm{y}}\right)$ and for the growing season from April to September $\left(M_{\mathrm{gs}}\right)$. Because of its minimal data requirement, this index has been widely used in the recent studies to describe the drought conditions or aridity for a given region (Rötzer et al. 2012; Pretzsch et al. 2013; Quan et al. 2013). The water supply for plant growth improves with increasing $M$ index. Within our study, $M_{\mathrm{gs}}$ varied between 12 and 24 and $\mathrm{M}_{\mathrm{y}}$ between 30 and 65 .

\section{Throughfall exclusion experiment and control plots}

We established 12 experimental plots in Kranzberg, i.e., 6 throughfall exclusion (TE) plots and 6 control plots (CO). Plot sizes varied between 110 and $200 \mathrm{~m}^{2}$. Summed over all plots, the total area was $868 \mathrm{~m}^{2}$ and $862 \mathrm{~m}^{2}$ for the $\mathrm{CO}$ and TE plots, respectively.

Before starting the throughfall exclusion experiment, soil and root trenching was performed in spring 2010. Soil was trenched to about $1 \mathrm{~m}$ deep and $15 \mathrm{~cm}$ wide and lined with a heavy-duty plastic tarp, impermeable to water and root growth, and refilled with the original soil material (Pretzsch et al. 2016). At about $1 \mathrm{~m}$ depth, a dense clay layer of tertiary sediments limits further downward-rooting (Häberle et al. 2015). In the six TE plots, roofs were installed about $3 \mathrm{~m}$ from the ground, completely underneath the stand 
canopy, to exclude all forms of precipitation. Roofs were first closed in 2014.

Roofs closed automatically in response to precipitation, and only stayed closed during precipitation events to prevent micro-meteorological and physiological effects (Pretzsch et al. 2014). Because the aim of the experiment was to induce summer drought, the roofs were kept open in the winter months. This resulted in small annual precipitation amounts for the throughfall exclusion plots in the years 2014-2018. The winter precipitation amounts for the 5 years of the experimental drought were below $150 \mathrm{~mm}$ (Fig. 1).

Due to the natural drought in 2015 a bark beetle infestation was observed across the entire Kranzberg Forest. Therefore, starting within the year 2015, bark beetle damage was confined through annually spraying the spruce crowns and stem surfaces with the contact insecticide Karate Forst liquid using the canopy crane.

Stand water was variable in the study years 1998-2018. Extreme dry years in 2003 and 2015 had significantly lower precipitation amounts compared to the rather moist years of 2001-2002 and 2005-2013. Accordingly, the Martonne index varied from 30 (2003) to 65 (2001) for the whole year and from 15 (2003) to 25 (2005) for individual growing seasons. Meteorological data were acquired from a nearby forest weather station "Freising", which is part of the Bavarian Environmental Monitoring System (LWF 2017). For further information about the Kranzberg Forest, see Göttlein et al. (2012); Häberle et al. (2012), and for more details about the KROOF experiment, see Pretzsch et al. $(2014,2018)$.

\section{Dendrometric survey}

A full survey of the Kranzberg Forest experimental plots in 2016 determined Norway spruce was 65 and European beech was 85 years old. Mean and dominant tree sizes were similar between the plots. The tallest trees (as used for calculating height of the dominant trees by Assmann and Franz 1963) had heights of $34.3 \mathrm{~m}$ (spruce) and $33.0 \mathrm{~m}$ (beech) indicating optimal growing conditions, i.e., site indexes of $\mathrm{O} 40$ according to the yield table of Assmann and Franz $(1963,1965)$ for Norway spruce and I. site class according to Schober (1975) for European beech.

The quadratic mean stem diameters at breast height were 27.1-36.4 cm, with mean heights of 27.2-36.4 m. Dominant tree diameters measured $41.4-44.9 \mathrm{~cm}$. The stem diameters were the lowest in the monospecific stands; in the beech by $20 \%$ lower than in spruce. Stem diameters were the highest in mixed-species stands; with beech again by about $20 \%$ lower than in spruce. The tree heights were similar in monospecific and mixed species stands; on average, beech is by $5 \mathrm{~m}$ lower than spruce. Collectively, there were 639-926 trees per hectare with a stand basal area of 54.0-60.1 $\mathrm{m}^{2} \mathrm{ha}^{-1}$, standing stem volume of 802-981 $\mathrm{m}^{3} \mathrm{ha}^{-1}$, and a mean periodic volume growth (1998-2016) of $19.4-26.3 \mathrm{~m}^{3} \mathrm{ha}^{-1} \mathrm{yr}^{-1}$. The lower values of the given ranges for tree number, stand basal area, standing volume, and volume growth of the monospecific beech stands, the upper values of the monospecific spruce stands, and the mixed species stands lie in between (for more stand information, see Pretzsch et al. 2014, 2018).

We utilized two data sources to evaluate tree diameter.

Since 1998, all trees of the Kranzberg Forest site were equipped with permanent diameter tapes with Vernier scales for circumferential recording to a $1 \mathrm{~mm}$ resolution (UMS, Germany). These data, excluding those from the throughfall exclusion experiment, were used to analyse the natural episodic drought in 2003 and 2015 to answer question Q1. Thus, diameter and circumferential stem growth at breast height were recorded for 268 spruce and 141

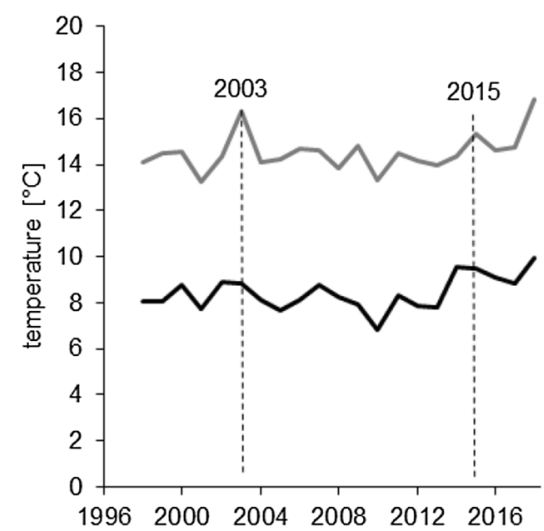

Fig. 1 Temperature (left), precipitation (middle), and Martonne index (right) since 1998 by years (black line) and growing seasons (MaySeptember, grey line) for the Kranzberg Forest site. The thin lines represent to conditions on the plots with throughfall exclusion from

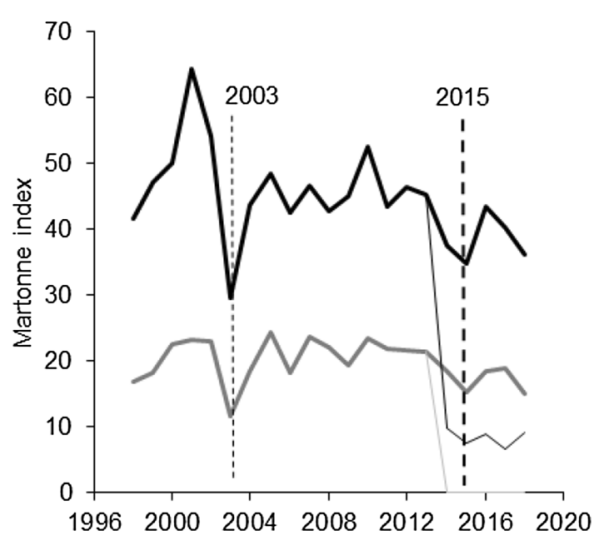

2014 to 2018 (TE plots). The years 2003 and 2015 are indicated by broken vertical lines and represent years with extremely low water availability 
beech trees for 2003 and for 214 spruce and 108 beech trees for 2015 (Table 1).

To analyse species response to extended drought (Question Q2), another 51 Norway spruce and 51 European beech were equipped with girth tapes and first measured in 2011. Half of the trees were under the throughfall exclusion roofs to mimic extreme summer drought conditions from 2014 to 2018, the other half served as controls (Pretzsch et al. 2016) (Table 2).

To compare the mortality of Norway spruce and European beech under episodic and extended drought (Question 3 ), we utilized both data sets, the long-term records from 1998-2018 (episodic droughts) and the time series from 2014 to 2018 (experimentally extended drought) (Table 4).
Based on the stem diameter, $d_{i}$ at the beginning of each year $i$ and the annual circumferential growth ic $_{i}$, equal to the annual diameter growth $\mathrm{id}_{i}=\mathrm{ic}_{i} / \pi$ within the year $i$, we calculated the annual basal area growth $\mathrm{iba}_{i}=\pi / 4 \times\left(\mathrm{d}_{i}+i \mathrm{~d}_{i}\right)^{2}-\pi / 4 \times \mathrm{d}_{i}^{2}=\pi / 4 \times\left(2 \times \mathrm{d}_{i} \times i \mathrm{~d}_{i}+\right.$ $i \mathrm{~d}_{i}$ ) (Assmann 1961, p. 52).

\section{Methods}

\section{Quantification of intra- and inter-specific environments}

Species composition within each tree's environment was quantified via an algorithm that counted the species identity of its six nearest neighbours (Fig. 2). The neighbours were

Table 1 Characteristics of Norway spruce and European beech in response to episodic droughts in 2003 and 2015

\begin{tabular}{|c|c|c|c|c|c|c|c|c|c|}
\hline Year 2003 & $n$ & & $d_{2002} \mathrm{~cm}$ & $h_{2002} \mathrm{~m}$ & $\mathrm{SDI}_{2002} \mathrm{ha}^{-1}$ & $\begin{array}{l}\mathrm{iba}_{2000-2002} \mathrm{~cm}^{2} \\
\text { year }^{-1}\end{array}$ & $\begin{array}{l}\mathrm{iba}_{2003} \mathrm{~cm}^{2} \\
\text { year }^{-1}\end{array}$ & Rt & $\begin{array}{l}\mathrm{iba}_{2004-2006} \\
\mathrm{~cm}^{2} \text { year }^{-1}\end{array}$ \\
\hline \multirow[t]{2}{*}{ N. spruce } & 268 & Mean & 28.12 & 26.79 & 860 & 21.19 & 8.6 & 0.41 & 13.64 \\
\hline & & $\pm \mathrm{SE}$ & 0.56 & 0.26 & 18 & 1.01 & 0.4 & & 0.71 \\
\hline \multirow[t]{2}{*}{ E. beech } & 141 & Mean & 22.76 & 24.59 & 805 & 8.95 & 6.84 & 0.76 & 8.58 \\
\hline & & $\pm \mathrm{SE}$ & 0.69 & 0.37 & 20 & 0.96 & 0.7 & & 0.93 \\
\hline Year 2015 & $n$ & & $d_{2014} \mathrm{~cm}$ & $\mathrm{~h}_{2014} \mathrm{~m}$ & $\mathrm{SDI}_{2014} \mathrm{ha}^{-1}$ & $\begin{array}{l}\mathrm{iba}_{2012-2014} \mathrm{~cm}^{2} \\
\text { year }^{-1}\end{array}$ & $\begin{array}{l}\mathrm{iba}_{2015} \mathrm{~cm}^{2} \\
\text { year }\end{array}$ & Rt & $\begin{array}{l}\mathrm{iba}_{2016-2018} \\
\mathrm{~cm}^{2} \text { year }^{-1}\end{array}$ \\
\hline \multirow[t]{2}{*}{ N. spruce } & 214 & Mean & 34.26 & 32 & 1009 & 16.84 & 8.58 & 0.51 & 11.02 \\
\hline & & $\pm \mathrm{SE}$ & 0.61 & 0.29 & 22 & 0.97 & 0.44 & & 0.65 \\
\hline \multirow[t]{2}{*}{ E. beech } & 108 & Mean & 27 & 21.1 & 898 & 6.53 & 7.03 & 1.08 & 6.75 \\
\hline & & $\pm \mathrm{SE}$ & 0.84 & 0.45 & 24 & 0.75 & 0.8 & & 0.74 \\
\hline
\end{tabular}

The mean stem diameter $d$, tree height $h$, and local stand density index, SDI, are given for autumn 2002 and 2014, i.e., before the start of the drought. The annual basal area increment, iba, is reported for the 3-year period before the drought, the drought year, and the 3-year period after the drought (PreDr, Dr, and PostDr, respectively). The ratio (bold letters) between the basal area in the 3-year periods before the drought and the dry year represents the drought resistance Rt

Table 2 Characteristics of the Norway spruce and European beech trees included in the throughfall exclusion experiment from 2011 to 2018 (throughfall exclusion from 2014 to 2018)

\begin{tabular}{|c|c|c|c|c|c|c|c|c|c|}
\hline Species & Group & $N$ & & $d_{2013} \mathrm{~cm}$ & $h_{2013} \mathrm{~m}$ & $\mathrm{SDI}_{2013}$ ha- 1 & $\begin{array}{l}\mathrm{iba}_{2011-2013} \mathrm{~cm}^{2} \\
\text { year }^{-1}\end{array}$ & $\begin{array}{l}\mathrm{iba}_{2014-2018} \mathrm{~cm}^{2} \\
\text { year }^{-1}\end{array}$ & $\begin{array}{l}\mathrm{iba}_{2014-2018} / \\
\mathrm{iba}_{2011-2013}\end{array}$ \\
\hline \multirow[t]{4}{*}{ N. spruce } & $\mathrm{CO}$ & 25 & Mean & 35.8 & 31.8 & 777 & 17.4 & 13.4 & 0.77 \\
\hline & & & $\pm \mathrm{SE}$ & 1.56 & 0.37 & 73 & 1.3 & 0.8 & \\
\hline & $\mathrm{TE}$ & 26 & Mean & 35 & 32 & 816 & 19.9 & 4.6 & 0.23 \\
\hline & & & $\pm \mathrm{SE}$ & 1.8 & 0.42 & 35 & 1.7 & 0.4 & \\
\hline Growth loss & & & & & & & & & 0.30 \\
\hline \multirow[t]{4}{*}{ E. beech } & $\mathrm{CO}$ & 25 & Mean & 28.2 & 28.3 & 851 & 6.8 & 8.5 & 1.25 \\
\hline & & & $\pm \mathrm{SE}$ & 1.8 & 0.68 & 44 & 0.9 & 0.9 & \\
\hline & TE & 26 & Mean & 28.8 & 27.9 & 823 & 7.1 & 4.9 & 0.69 \\
\hline & & & $\pm \mathrm{SE}$ & 1.8 & 0.65 & 43 & 1.1 & 0.5 & \\
\hline Growth loss & & & & & & & & & 0.55 \\
\hline
\end{tabular}

The current mean stem diameter $d$, and tree height $h$, and the local stand density index, SDI, are given for autumn 2013, i.e., before the start of the throughfall exclusion. The annual tree diameter increment, id, and basal area increment, iba, are reported for the 3-year period before the drought (2011-2013) and for the throughfall exclusion period (2014-2018) 

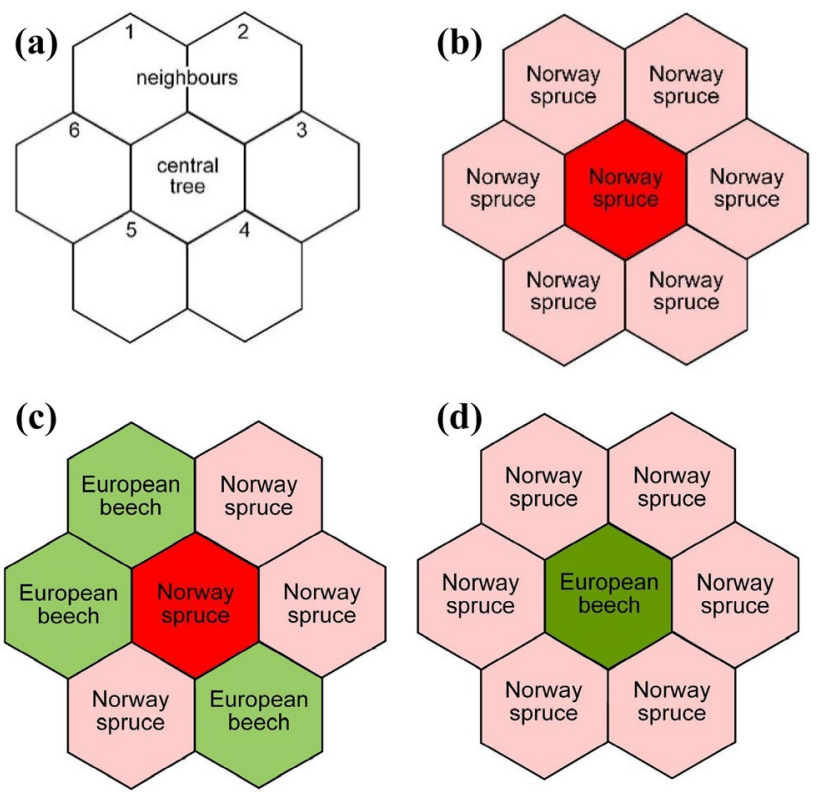

Fig. 2 Method of characterizing a central tree's (tree in the middle of the respective hexagons) intra- or inter-specific environment; this approach was developed as an algorithm for automatic sorting into the groups ss, sb, bs, and bb. a In mature stands, trees grow in a hexagonal distribution pattern and have 6 direct neighbours (no. 1...6) on average. b In this case, Norway spruce is in the centre and the environment is by $100 \%$ ( 6 trees/ 6 trees $\times 100$ ), the category is ss. c Here, Norway spruce is surrounded by three Norway spruce and three European beech, the admixture of another species apart from Norway spruce is $>0$ and the group is sb. d Here, the grouping is bs, as beech is surrounded by Norway spruces (ss Norway spruces in neighbourhood of Norway spruces, $s b$ Norway spruces in neighbourhood of European beeches, European beeches in neighbourhood of European beeches, $b s$ European beeches in neighbourhood of Norway spruces)

chosen irrespectively of their size and social position; due to its advanced development state, the stand mainly consisted of codominant and dominant trees. Based on the results, we assigned each tree to one of four groups, ss = spruce surrounded by spruce, $\mathrm{sb}=$ spruce surrounded by beech, $\mathrm{bb}=$ beech surrounded by beech, and $\mathrm{bs}=$ beech surrounded by spruce.

In an advanced stand development phase like Kranzberg Forest, the trees in even-aged stands grow more or less in a hexagonal pattern (Prodan 1968a, b), i.e., each tree has on average six direct neighbours $(n=1 \ldots 6)$ (Fig. 2a). Figure $2 \mathrm{~b}$ shows an ss constellation where the central tree is a spruce tree surrounded by spruces. The proportion of other tree species in its environment is $0 \%$ as. The constellation in Fig. 2c results analogously in a group membership of sb and $m_{\text {other }}=3 / 6 \times 100=50 \%$. Figure $2 \mathrm{~d}$ shows a constellation of bs where beech is surrounded just by spruces, so that $m_{\text {other }}=6 / 6 \times 100=100 \%$. We choose a rather strict separation between monospecific and mixed environments. As soon as the environment included another species other than the species of the central tree, it was re-characterized.
In other words, only completely pure tree groups were characterized as ss or bb.

\section{Calculation of resistance and resilience}

The response of tree basal area increment, iba $\left(\mathrm{cm}^{2} \mathrm{yr}^{-1}\right)$, to the natural drought stress events in the years 2003 and 2015 was characterized by three different phases: (a) the growth PreDr in the 3-year-periods before the drought years 2003 and 2015, respectively, (b) the growth Dr during the drought years 2003 and 2015, respectively, and (c) the 3-year growth PostDr after the two drought years 2003 and 2015, respectively (Lloret et al. 2011). Indices for resistance, Rt $=\mathrm{Dr} / \mathrm{PreDr}$, recovery, $\mathrm{Rc}=\mathrm{PostDr} / \mathrm{Dr}$, and resilience, $\mathrm{Rs}$ $=$ postDr/PreDr, were used for the characterization of the stress response patterns. Resistance quantifies the growth decrease from the pre-drought period to the drought period. $\mathrm{Rt}=1$ indicates complete resistance; the further the value decreases below $\mathrm{Rt}=1$, the lower the resistance. Recovery describes the tree growth response after the drought period. $\mathrm{Rc}=1$ indicates a persistence at the low-growth level even after the drought period, values of $\mathrm{Rc}<1$ indicate a further decline, and values $\mathrm{Rc}>1$ represent a recovery from the drought period. Resilience is defined as tree growth after the drought period compared to the tree growth before the drought period. Rs values $>=1$ indicate high resilience with growth levels that are equal to or above the level before the drought event; Rs values $<1$ indicate low resilience with growth levels below the one before the drought period. For a more detailed description of these indices, see Lloret et al. (2011).

\section{Indexing, trend elimination, and smoothing}

To evaluate the individual tree growth response to drought, we used the original annual iba data from the permanent girth tapes. We used the original data without trend elimination, smoothing, etc. due to the following reasons. (i) in contrast to the annual diameter or tree ring width growth, the trends of the annual iba growth rates tracked more or less parallel to the $x$-axis, except near drought years (2003, 2015) and the throughfall exclusion period (2014-2018). Therefore, no significant up- or down-age trends would bias the resistance or resilience analyses. (ii) The time span from 1998-2018 was too short to smooth or eliminate any trend, since in this time span, there were two natural drought events $(2003,2015)$ and one experimentally induced growth decline resulting from water limitation. Any attempt to fit a smooth curve through the 20-year-period would be questionable as the period was too short and more than a quarter of the period would have been overlayed by non-age-related disturbances; (iii) because the stands are even-aged and the trees all show more or less the same age trend. This applies 
especially for the trees of the precipitation exclusion experiment, as they were all dominant and even more homogeneous in the growing conditions and trends than the full data set. (iv) We compared the results only between groups with the same general age trend (Norway spruce vs. European beech, intra- inter-specific growth, TE vs. CO), so any influence of the age on the resistance or resilience indices should be eliminated as the trends in both groups were similar.

\section{Estimation of mortality rates}

Mortality rate calculations were based on the tree numbers, $N$, at the beginning $N_{\mathrm{b}}$, and end $\mathrm{N}_{\mathrm{e}}$, of the observation periods. Using the compound interest formula, $N_{\mathrm{e}}=N_{\mathrm{b}} \times 1.0 \mathrm{~m}^{n}$, the mortality rates, m, and percent of mortality, $m_{\%}=m \times 100$, were calculated for defined groups of trees (e.g., CO and TE). Hereby, n represents the length of the period in years. For our purpose, the basic equation $N_{\mathrm{e}}=N_{\mathrm{b}} \times 1.0 m^{n}$ was transformed to $1.0 m=\sqrt[n]{N_{\mathrm{e}} / N_{\mathrm{b}}}$ and $\mathrm{m}=1-\sqrt[n]{N_{e} / N_{b}}$ to arrive at the mortality rate $\mathrm{m}$. Note that the term $1.0 \mathrm{~m}$ is the convention of writing $1.0+\mathrm{m}$ in financial mathematics.

Mortality rates were calculated separately for the tree groups under episodic and experimentally extended drought and separately within these groups for Norway spruce and European beech.

The statistical software R 3.4.1 (R Core Team 2018) was used for all calculations, in particular the glht and $t$ test functions for group comparison and lme function for regression analyses from the nlme package (Pinheiro et al. 2017).

\section{Results}

\section{Growth response to natural episodic drought}

Trees exposed to throughfall exclusion were excluded from the results presented in this section $\left(=T_{\mathrm{nt}}\right)$. For the drought events of 2003 and 2015, we show the periodic basal area increment in the 3 years before, during, and after the drought years (PreDr, Dr, PostDr) (Table 1). The long-term trend in annual basal area $( \pm \mathrm{se})$ growth from 1998 to 2018 decreased slightly for Norway spruce and remained stable for European beech (Fig. 3). This longterm trend, however, was interrupted by dips in annual growth in 2003 and 2015, especially for Norway spruce. In general, European beech was much more resistant to the drought years.

Norway spruce had reduced growth in both drought years (2003 and 2015), while European beech was only slightly reduced in 2003 and even increased in 2015 (see bold printed ratios of resistance Rt in Table 1). These data clearly show that the growth of Norway spruce is severely negatively impacted (50-60\%) by drought, while European beech trees are much less effected.

The basal area increment of Norway spruce, in general, grew twice as much as European beech. In the drought year 2003, Norway spruce's growth decreased to $41 \%$ and European beech to $\mathrm{Rt}=76 \%$ compared to the 3 -year-period before. After 2003, spruce was slower to recover than beech. In 2015, Norway spruce was also less resistant than European beech: spruce decreased to $\mathrm{Rt}=51 \%$ of the initial increment level in response to the drought event, while beech increased incremental growth, surpassing the rate of growth in the 3-year-period before the drought (see bold numbers in Table 1).

To reveal any intra- and inter species-specific response pattern to drought, we analysed the growth response in the drought years 2003 and 2015 (Dr) compared with the 3-yearperiod before (PreDr) and after (PostDr) the events. Drought had a much stronger effect on Norway spruce growth compared to European beech despite their intra- and inter-specific environments (Fig. 4a). Since the relationships between the species, and between the intra- and inter-specific differences were similar, we show the results for 2003 only (Fig. 4).

Interestingly, Norway spruce was 10-20\% less effected by drought when growing in the environment of beech trees (see sb in Fig. 4b), while reductions in spruce's growth was greater in intra-specific spruce environments in 2003. Intraspecific competition (group ss, $n=192$, mean $0.43 \pm 0.02$ ) had significantly reduced growth $(p<0.05)$ compared
Fig. 3 Mean annual basal area increment $( \pm \mathrm{SE})$ of $(\mathbf{a}) \mathrm{N}$. spruce $(n=268)$ and $(\mathbf{b}) \mathrm{E}$. beech $(n=141)$ from 1998 to 2018 excluding the trees under the throughfall exclusion roofs since 2014 (tree numbers refer to the year 2003). The broken vertical lines mark the drought event years 2003 and 2015
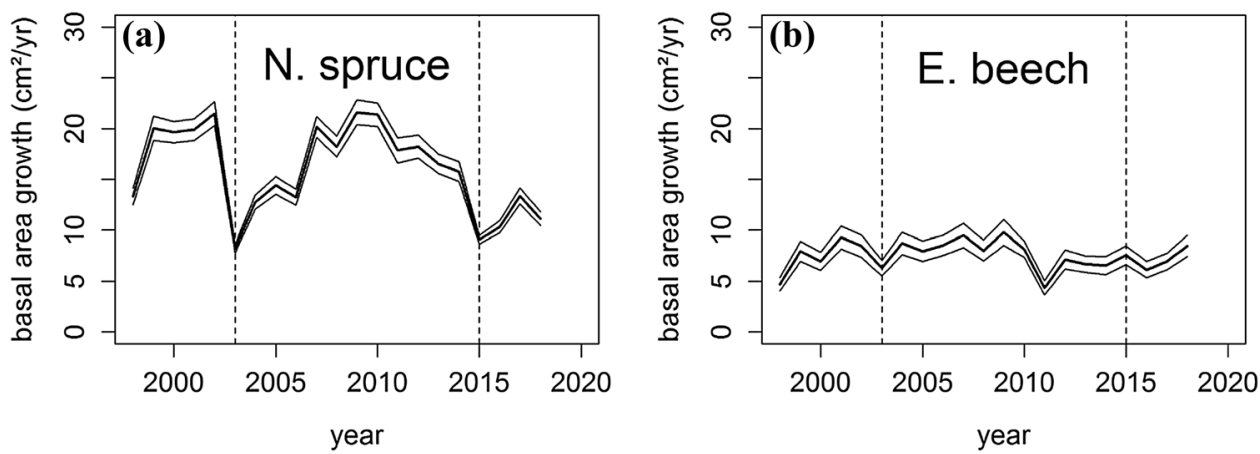


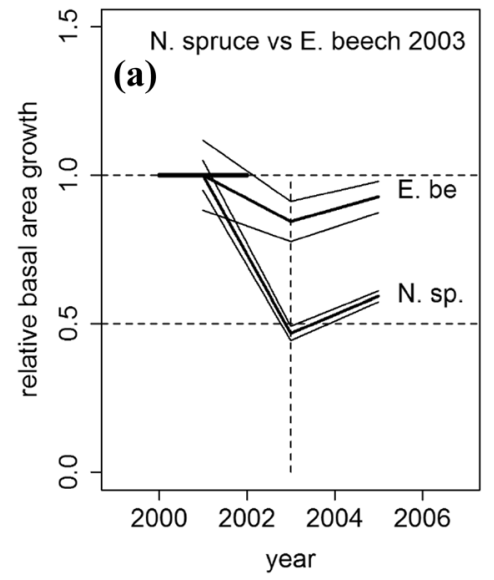

Fig. 4 Visualization of the growth response to the 2003 drought based on the annual basal area increment $( \pm \mathrm{SE})$. The pre-drought growth in the period 2000-2002 is set to 1.0 (1.0-line). The growth in the drought year 2003 and in the post-drought period 2004-2006 was sketched in relation to this reference level. a On average, growth of Norway spruce (N. sp.) dropped steeply and recovered slowly, European beech (E. be.) was hardly affected by the 2003 drought. b When Norway spruce grew in inter-specific environment with beech (sb, broken lines), it was $20 \%$ less affected by drought compared

to inter-specific competition (group $\mathrm{sb}, n=62$, mean $0.56 \pm 0.05$ ).

European beech, on the other hand, were significantly more effected under drought in inter-specific environments but recovered quickly (see bs in Fig. 4c). Beech growing in the environment of other beech trees, in contrast, were much less affected by drought (see bb in Fig. 4c). In 2003, beech trees growing intra-specifically (group bb, $n=93$, mean $0.87 \pm 0.07)$ grew significantly more $(p<0.05)$ than trees in inter-specific environments (group bs, $n=23$, mean $0.67 \pm 0.05$ ). This means that when beech grew in an inter-specific environment, it was by $23 \%$ more affected by drought compared to intra-specific conditions. This implies that in dry years, Norway spruce benefited from growing in mixed stands, obviously at the expense of European beech, as trees of the latter species significantly reduced their growth in inter-specific neighbourhood. Growth responses to experimentally extended drought by throughfall exclusion

Before the start of the throughfall exclusion experiment in 2014, we measured tree growth on the $6 \mathrm{CO}$ and 6 TE plots for the years 2011-2013 to have an initial growth level reference. Compared to spruce, beech had less than half the mean basal area increment in the reference period 2011-2013 with some variation between the $\mathrm{CO}$ and TE plots of each species (Table 2). On the $6 \mathrm{CO}$ and $6 \mathrm{TE}$ plots, we recorded the course of growth of in total 102 dominant trees. The following analyses are based on 51 trees for each of the two species with 25 trees on the control plots and 26 on the treatment plots. Trees that suffered mortality were excluded from the analyses of growth reactions.

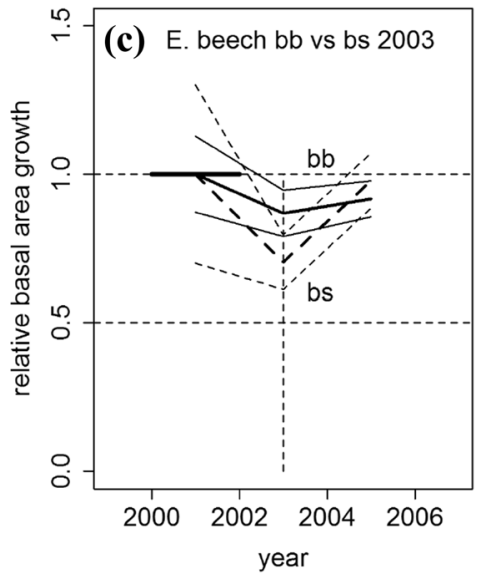

with intra-specific constellations (ss). c When European beech grew in inter-specific environment with spruce (bs, broken lines), it was more affected by drought by app. $20 \%$ compared with intra-specific constellation (bb). However, the recovery and resilience was much faster in inter-specific compared with intra-specific constellation. (ss growth of Norway spruces in neighbourhood of Norway spruces, $s b$ growth of Norway spruces in neighbourhood of European beeches, $b b$ growth of European beeches in neighbourhood of European beeches, $b s$ growth of European beeches in neighbourhood of Norway spruces)

Norway spruce grew less in the period of 2014-2018 compared to the prior years, most likely due to the dry year in 2015. Trees in the CO plots exhibited a slight growth decrease from 2011 to 2013 compared to 2014-2018 from 17.4 to $13.4 \mathrm{~cm}^{2} \mathrm{yr}^{-1}$. However, on the TE plots, the decrease was much more severe from 19.9 to $4.6 \mathrm{~cm}^{2} \mathrm{yr}^{-1}$.

Using the relative growth $(0.77)$ of the $\mathrm{CO}$ plot as a reference for the relative growth on the TE plots $(0.23)$, the growth level was 0.30 (see Table 2, in bold and italic numbers), i.e., a loss of $70 \%$ in annual growth.

On the CO plots, European beech grew more in the period 2014-2018 than in the years 2011-2013, maybe because of late frost event in spring 2011 (Bayerische Forstverwaltung 2015). On the TE plots, we found a medium decrease from 7.1 to $4.9 \mathrm{~cm}^{2} \mathrm{yr}^{-1}$, i.e., a relative decrease by $31 \%$. Using, analogously to Norway spruce, the relative growth (1.25) of the $\mathrm{CO}$ plot as a reference for the relative growth on the TE plots was 0.69 ; the growth level was 0.55 (see Table 2, in bold and italic numbers), i.e., a loss of $45 \%$ of basal area growth.

The basal area increment of Norway spruce, in both CO and TE plots decreased over time, mainly a result of the dry year in 2015 (Fig. 5, a, b). However, in the TE plots (Fig. 5b), the decrease was drastically more pronounced. In 2016 and 2017, a few of the trees had an upward trend, i.e., demonstrated recovery.

Most European beeches had a positive growth trend on the CO plots (Fig. 5c) and a negative trend on the TE plots (Fig. 5c) during the treatment period. However, some beech trees acclimated or even recovered during the 

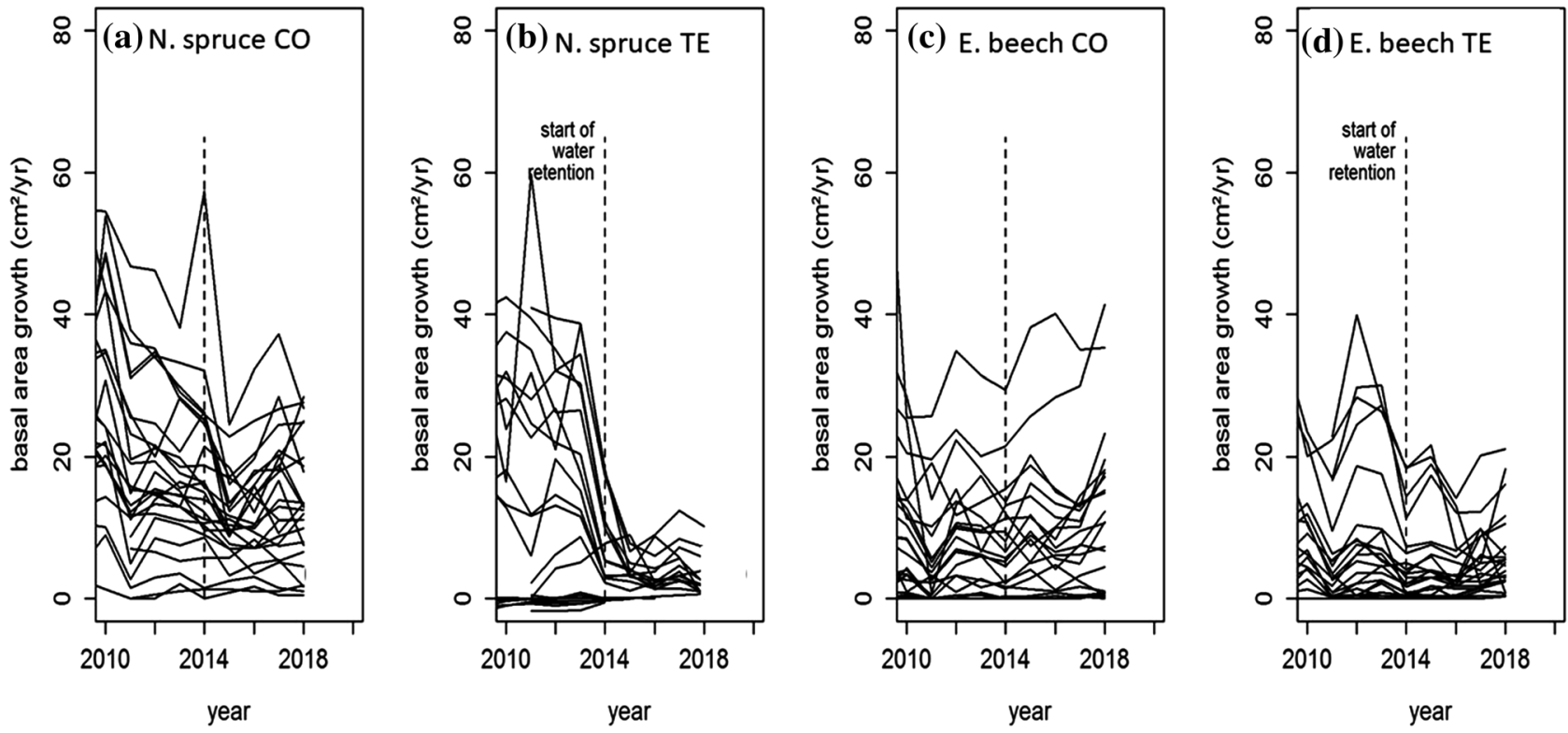

Fig. 5 Annual basal area increment of individual trees from 2010 to 2018 shown for N. spruce and E. beech on the CO and TE plots. The vertical lines show the beginning of the throughfall exclusion

throughfall exclusion period, i.e., in the years 2016-2018 (Fig. 5d).

In summary, we found clear negative responses to the experimentally induced drought in Norway spruce; the average loss in annual basal area growth amounted to $70 \%$ (Table 2). We found medium drought-induced negative

(2014) on the TE plots. On the TE plots (2014-2018), Norway spruce reduced its growth (b), while European beech responded minimally to drought (d)

responses in European beech; the average loss in annual basal area growth amounted to $45 \%$ (Table 2). Finally, we found some indications of acclimation and recovery for both tree species (see Fig. 6).

To more closely examine the stress response to the throughfall exclusion, we analysed the annual basal area
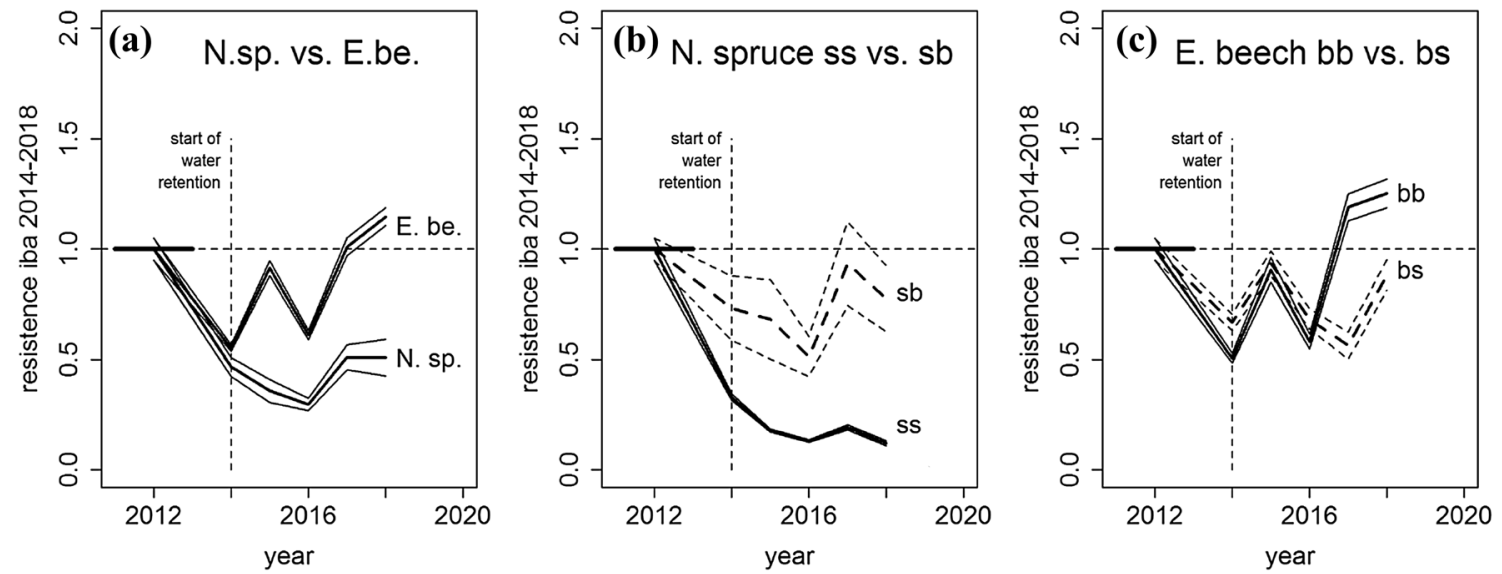

Fig. 6 Visualization of the resistance to the 2014-2018 throughfall exclusion based on the annual basal area increment $( \pm S E)$. Predrought growth in the period 2011-2013 is set to 1.0 (1.0-line, solid black), the growth in the years of the throughfall exclusion is shown in relation to the pre-drought level. a On average, growth of Norway spruce (N. sp.) dropped steeply and recovered slowly; growth of European beech (E. be.) dropped less strongly or even increased above the level of the pre-drought period after four years. b When Norway spruce grew in inter-specific environments with European beech (sb, broken lines), it was $20-30 \%$ less affected during the throughfall exclusion and recovered remarkably in subsequent years compared to spruce in an intra-specific constellation (ss). c When European beech grew in an inter-specific environment with spruce (bs, broken lines), the beech trees grew better in the first years of drought, but then fell behind the growth of beech in intra-specific environment (bb) (ss growth of Norway spruces in neighbourhood of Norway spruces, $s b$ growth of Norway spruces in neighbourhood of European beeches, $b b$ growth of European beeches in neighbourhood of European beeches, $b s$ growth of European beeches in neighbourhood of Norway spruces) 
Table 3 Comparison of the drought resistance on the TE plots in the experimentally induced drought period 2014-2018 on annual basis

\begin{tabular}{|c|c|c|c|c|c|c|c|c|}
\hline \multirow[t]{2}{*}{ Groups } & & \multirow[t]{2}{*}{$n$} & \multirow[t]{2}{*}{ Statistics } & \multicolumn{5}{|c|}{ Resistance iba [year]/ iba [2011-2013] } \\
\hline & & & & 2014 & 2015 & 2016 & 2017 & 2018 \\
\hline \multirow[t]{2}{*}{ N .spruce } & all & 14 & Mean & 0.46 & 0.36 & 0.29 & 0.51 & 0.51 \\
\hline & & & SE & \pm 0.04 & \pm 0.05 & \pm 0.03 & \pm 0.06 & \pm 0.08 \\
\hline \multirow[t]{2}{*}{ E. beech } & & 21 & Mean & 0.55 & 0.91 & 0.61 & 1.01 & 1.14 \\
\hline & & & SE & \pm 0.01 & \pm 0.03 & \pm 0.02 & \pm 0.04 & \pm 0.04 \\
\hline Significance & & & & n. sig. & $p<0.01$ & $p<0.01$ & $p<0.05$ & $p<0.05$ \\
\hline \multirow[t]{4}{*}{ N. spruce } & Ss & 8 & Mean & 0.32 & 0.18 & 0.13 & 0.19 & 0.12 \\
\hline & & & SE & \pm 0.01 & \pm 0.01 & \pm 0.01 & \pm 0.01 & \pm 0.01 \\
\hline & $\mathrm{Sb}$ & 6 & Mean & 0.73 & 0.68 & 0.51 & 0.93 & 0.77 \\
\hline & & & SE & \pm 0.03 & \pm 0.03 & \pm 0.09 & \pm 0.09 & \pm 0.06 \\
\hline Significance & & & & $p<0.01$ & $p<0.01$ & $p<0.05$ & $p<0.05$ & $p<0.05$ \\
\hline \multirow[t]{4}{*}{ E. beech } & $\mathrm{Bb}$ & 15 & Mean & 0.67 & 0.94 & 0.58 & 1.19 & 1.25 \\
\hline & & & SE & \pm 0.02 & \pm 0.05 & \pm 0.04 & \pm 0.06 & \pm 0.06 \\
\hline & Bs & 6 & Mean & 0.5 & 0.91 & 0.68 & 0.56 & 0.88 \\
\hline & & & SE & \pm 0.04 & \pm 0.06 & \pm 0.03 & \pm 0.06 & \pm 0.07 \\
\hline Significance & & & & n. sig. & n. sig. & $p<0.01$ & $p<0.01$ & $p<0.05$ \\
\hline
\end{tabular}

In the first section, all Norway spruce are compared and tested against all European beech. In the second section of the table, Norway spruce in an intra-specific environment are compared with Norway spruce in an inter-specific environment (ss treated vs. sb treated). In the third section, European beech in an intraspecific environment is compared with European beech in an inter-specific environment with spruce (bb treated vs. bs treated) increments in the years 2011-2018 (Fig. 6 and Table 3). We first compared the performance of the species (Fig. 6a). Note that, in Fig. 6, the reference period 2011-2013 was marked by a bold horizontal line at level 1.0, reaching from 2011 to 2013. The mean year of this period is 2012 . To visualize the growth after this reference period, we drew a connecting line from 2012, the mean of this reference period, to the relative growth in the years 2014; from there, we continued the line to the relative growth in 2015-2018.

Both species strongly reduced their growth in 2014, the first year after the throughfall exclusion experiment was initiated. Norway spruce continued to decrease over time but stabilized in 2016-2018, while European beech stabilized earlier and recovered to the initial level by 2018 (Table 3).

As the average growth of European beech in the reference period 2011-2013 was probably reduced by the late frost in spring 2011, we also calculated the growth response in the years afterwards after elimination of the year 2011 from the reference. However, this hardly changed the results as the beeches quickly recovered already in 2012 from the late frost. This is visible in Fig. $5 \mathrm{c}$ and d, where the course of beech growth shows a strong upward trend in 2012 .

For Norway spruce in particular, environment effected growth after experimentally extended drought stress (Fig. 6b). Spruces growing in the environment of other spruces exhibited decreased growth much more than spruces close to beech. There was a significantly lower stress response and greater growth in spruce growing in inter-specific environments compared with those growing in an intra-specific constellation (Table 3).

Beech trees in both inter- and intra-specific conditions, however, responded to drought similarly at first (Fig. 6c). However, from 2016, we found significant differences between the two groups, i.e., beech in inter-specific environments outgrew those with spruce as neighbours (Table 3).

\section{Mortality of Norway spruce and European beech caused by experimentally extended drought}

Mortality of trees within the plots with experimentally extended drought would certainly impact the water supply and growth of the remaining trees, and, therefore, analysed the mortality of Norway spruce and European beech in the TE plots compared with untreated reference groups, i.e., the CO group and the group of all trees of the site Kranzberg Forest without the ones of the throughfall exclusion experiment $\left(=T_{\mathrm{nt}}\right)$ to improve the interpretation of our results.

The mortality rate under natural conditions between 1998 and 2018 was $1.24 \%$ for Norway spruce, $2.00 \%$ for European beech, and $1.50 \%$ for the total stand. In the period 1998-2019, no tree thinning occurred in the plots, so the given mortality rates represent the mean dropout under selfthinning conditions (Table 4).

The throughfall exclusion experiment $\mathrm{CO}$ plots were also not thinned. Mortality rates of $0.00 \%$ Norway spruce, $0.83 \%$ European beech, and $0.45 \%$ for the total stand occurred between 2011 and 2018. Tree mortality under throughfall 
Table 4 Tree numbers at the beginning, $N_{\mathrm{b}}$, and at the end, $N_{\mathrm{e}}$ of the defined observation periods for the trees of the $T_{\mathrm{nt}}$ group and for the trees of the TE and the CO plots

\begin{tabular}{llllllll}
\hline Group & Species & Begin & $N_{\mathrm{b}}$ & End & $N_{\mathrm{e}}$ & $\begin{array}{l}\text { Number of } \\
\text { years }\end{array}$ & $\begin{array}{l}\text { Mortality } \\
\text { rate in } \% \\
m_{\%}\end{array}$ \\
\hline$T_{\mathrm{nt}}$ & & & & & & & 1.24 \\
& N. spruce & 1998 & 277 & 2018 & 213 & 21 & 2.00 \\
& E. beech & 1998 & 156 & 2018 & 102 & 21 & 1.50 \\
CO & Total & 1998 & 433 & 2018 & 315 & 21 & 0.00 \\
& N. spruce & 2011 & 26 & 2018 & 26 & 8 & 0.83 \\
& E. beech & 2011 & 31 & 2018 & 29 & 8 & 0.45 \\
TE & Total & 2011 & 57 & 2018 & 55 & 8 & 7.45 \\
& N. spruce & 2011 & 26 & 2018 & 14 & 8 & 1.46 \\
& E. beech & 2011 & 27 & 2018 & 24 & 8 & 4.07 \\
\hline
\end{tabular}

The mortality rate was calculated based on the compound interest formula $N_{\mathrm{e}}=N_{\mathrm{b}} \times 1.0 \mathrm{~m}^{n}$, $1.0 m=\sqrt[n]{N_{\mathrm{e}} / N_{\mathrm{b}}}, \mathrm{m}=1-\sqrt[n]{N_{\mathrm{e}} / N_{\mathrm{b}}}, m_{\%}=m \times 100$ (see program KROOF2.mort.R) exclusion was much higher than for the $T_{\mathrm{nt}}$ group. However, since 2011-2018 does not encompasses as many years as the period from 1998-2018 and climatic conditions differed between the two periods, this comparison should be viewed within the context of its limitations.

The comparison of the CO plot's with the TE plot's mortality rates is more interesting, as they refer to the same time period 2011-2018. Trees in plots with extended experimental drought had mortality rates of $7.45 \%$ for Norway spruce, $1.46 \%$ for European beech, and $4.07 \%$ for the entire stand (Table 4). Therefore, both species had higher mortality in TE plots compared with the CO plots, and in the case of Norway spruce, the mortality rate was five times as high as the longterm mortality of the $T_{\mathrm{nt}}$ group. The ranking of the mortality rate between the considered groups was $s s>s b>b s>b b$. Although it is difficult to assess the final causes of mortality (drought, bark beetle, and competition for light), we assume that in case of Norway spruce, most of the mortality (70\%) was caused by bark beetle despite of the chemical control measures, some directly by drought $(20 \%)$ and the rest by self-thinning due to competition (10\%). The latter assumptions are based on the annual assessment of the vitality of all individual trees on the 12 plots. An indication for mortality caused by bark beetle were boring holes in the bark, boring dust on the ground and galleries under the bark. We assumed dropout by self-thinning in case of subdominant trees that became continuously more competed by their neighbours in the previous years. In case of those trees with transparent crowns that died although showing neither bark beetle infestation nor suppression by neighbours, we assumed a dropout by drought stress.

\section{Discussion}

Many studies have tackled species-specific drought resistance outcomes in monoculture tree plantings. However, species structural and functional trait differences can result in a particular species-specific stress responses when growing in monocultures (Bréda et al. 2006; Niinemets and Valladares 2006) and a potential reduction of stress response when growing in mixture (Ammer 2019; Grossiord 2018). Norway spruce is commonly assessed as a highly drought susceptible species (Lévesque et al. 2013; Zang 2012), while European beech, although under debate (Rennenberg et al. 2004), is less affected by drought (Ammer et al. 2005; Ewald et al. 2004). Whether tree species growing in mixtures can reduce drought susceptibility may depend among other things on the species combination (Metz et al. 2016; Pretzsch et al. 2013), the site conditions (Grossiord et al. 2014; Trouvé et al. 2017), and the stand density (Bottero et al. 2017; Sohn et al. 2016).

Norway spruce and European beech represent species with different hydraulic systems (xylem anatomy). Spruce exhibits a more isohydric strategy (Lyr et al. 1992), reducing stomatal conductance at early stages of soil drought. In contrast, beech displays a more anisohydric strategy, with less stomata sensitivity to soil drought, allowing for more carbon gain, and stem and root growth during prolonged time spans under mild to moderate drought (Leuschner 2009; Nikolova et al. 2009). These differences along with the high drought susceptibility of Norway spruce at the edge of its natural range and the maximum stand density within the experimental stands used here may have contributed to the substantial and lasting decrease in spruces' growth compared to the minor growth reduction of beech under both episodic (Fig. 4a) and extended (Fig. 6a) drought.

Whether the potential of resource use, stress reduction, and even overyielding in mixed stands can be exploited by a given species assemblage depends on the respective site 
conditions (Forrester et al. 2014). Under ample water supply, e.g., a spatial or temporal complementarity of water uptake may be less useful than under drought. This explains why even rather complementary tree species may change the way which they grow in mixtures from beneficial to disadvantageous along ecological gradients (Pretzsch et al. 2015).

The temporal shift in the water uptake, i.e., that the transpiration of Norway spruce starts earlier than European beech (Rötzer et al.2017a), may explain the benefit of Norway spruce when growing in inter-specific neighborhood in the analysed stands (Figs. $4 \mathrm{~b}$ and $6 \mathrm{~b}$ ). We hypothesize that spruce in proximity to beech benefits from a better water supply in the spring when beech is still leafless (see e.g. Rötzer et al. 2017a). This pre-emptive water uptake by spruce may reduce the water availability and growth of beech in the environment of spruce as observed on the TE plots of this study. This assumption is substantiated by measurements of soil moisture and water uptake by depth (Goisser et al. 2016) and micro-dendrometer trajectories (Rötzer et al. 2017b) which show seasonal shifts during spring drought and negative (during summer drought) soil moisture effects of beech neighboured by spruce. This underlines that the time of the year in which a drought occurs in mixed-species stands determines which species may benefit or lose in interspecific neighbourhood.

The slight basal area growth recovery of both species after the initial downtrend of under experimentally extend drought (Fig. 6) is of special interest as it suggests an ability to adapt to drought stress.

Enhanced compensation growth of fine roots upon drought (e.g., in beech, Meier and Leuschner et al. 2008), adjustment of the mycorrhiza to an increased share of longdistance exploration types (Nickel et al. 2018), and acclimation of the branches and leaves to drought (Barbeta and Penuelas, 2016; Tomasella et al. 2018) may be effective measures of drought acclimation.

An increase of mortality of Norway spruce, e.g., caused by bark beetle attacks combined with extended drought, may reduce the stand density and, in this way, may improve the water supply of the remaining trees on the TE plots and contribute to their recovery.

The analysed stands are within the range of natural occurrence of European beech but at the limit of the distribution range of Norway spruce (Bayerisches Staatsministerium für Ernährung, Landwirtschaft und Forsten (2001). The site conditions at Kranzberg Forest allow both species nearly maximum productivity, indicated by the site indexes of $\mathrm{O} 40$ according to the yield table of Assmann and Franz (1963) for Norway spruce and site class I, according to Schober (1975) for European beech. But growing at the edge of its ecological niche, Norway spruce achieved its maximum productivity in years with ample water supply and when disturbances [e.g., bark beetle (Ips typographus L.) or gregarious spruce sawfly (Pristiphora abietina (Christ.) (Hym., Tenthredinidae)] were controlled by forest management (Skatulla et al. 1989; Wermelinger 2004). Living at the edge of an ecological niche can have amplified deleterious effects on species when small temporal environmental changes can have strong non-linear effects on growth and fitness. For Norway spruce, this means that the trees may be more susceptible to decline in drought years (Biermayer and Tretter 2016; Kölling et al. 2009) or that the trees have a requirement for facilitated positive interspecific interactions (Brandl and Falk 2019; del Río et al. 2014; Pretzsch et al. 2012). In addition, Norway spruce is generally characterized by rather high mortality rates also in its natural range (Synek et al. 2020).

The restrictions and risks of cultivating Norway spruce beyond its natural occurrence are important to understand for forest practice. Because of its high productivity, excellent timber, and multi-purpose use, Norway spruce is highly valued and has a long history and tradition, especially in monocultures far off its natural range in mountainous regions of Central Europe and the Boreal region. The increasing tree damage in monocultures by both biotic and abiotic (snow breakage, wind) disturbances have resulted changes to forest practices including a move away from planting Norway spruce solely in monocultures. An alternative is mixed stand plantings that support more stable tree species, e.g., European beech, silver fir, Douglas-fir, or Scots pine, while maintaining a significant population of Norway spruce.

The silvicultural tools mitigating forest damage from drought are comprised of a selection of well acclimated species and provenances (Atzmon et al. 2004; Arend et al. 2011; Bolte et al. 2010; Zang et al. 2011), downregulation of stand density (D'Amato et al. 2013; Sohn et al. 2016), and thinning (Gebhardt et al. 2014; Pretzsch et al. 2018; Rodríguez-Calcerrada et al. 2011). An additional measure may be increased tree species mixtures although not yet rated effective for drought mitigation in general (Grossiord 2018). Our study provides an example of how tree mixtures can reduce stress and allow for continued growth of Norway spruce when growing closely mixed with European beech. This required single tree mixture, whereas most common in forest practice are mixtures in groups or clusters. Cultivation of European beech in two or three groups or clusters embedded in Norway spruce stands has the economic advantages of facilitated beech establishment (Wagner et al.2010), better timber quality when growing in intra-specific environment (Höwler et al. 2019; Pretzsch and Rais 2016), and an easier harvest (Hanewinkel 2001). In the common group or cluster mixtures, Norway spruce would most likely mainly benefit 
when growing at the edges of the beech groups, in close environment of beech, but not in the other zones. This means that Norway spruce, growing in the warm dry limit of its natural distribution, seems to be facilitated most effectively when growing directly next to groups of European beech which is natural in this area. This suggests that the choice of a climate smart species mixing pattern might be another tool in the silvicultural package of measures mitigating drought damages.

\section{Conclusions}

Experimentally extended drought established by a 5-year throughfall exclusion experiment enabled new insights into how Norway spruce and European beech may respond to future climate change scenarios that predict longer and more intense drought periods. The extended drought caused a drastically reduced growth in the first years, followed by a less severe decline in the subsequent period. To some extent, both species were able to acclimate to the drought and recover from the initial growth collapse, after exposure to episodic droughts. Norway spruce benefited significantly from growing in the environment of European beech, while beech overcame drought slightly better in intra- specific environments.

The considered site is representative for many areas in Southern Germany where Norway spruce is cultivated beyond its natural range, and while it can achieve optimal productivity under average climatic conditions, which becomes susceptible to drought and biotic disturbances during dry years.

Many recent studies show that tree species mixing can result in overyielding compared to monospecific stands and can increase the resistance of Norway spruce against biotic disturbances (e.g. bark beetle damages). The mixture of the highly productive and economically valuable Norway spruce with stabilizing trees species such as European beech may reconcile economy with ecology. The revealed drought stress relief of Norway spruce in inter-specific environments may be a strong argument in favour of a transition to mixed species forest stands and their superior ecosystem services.

\section{Author contributions statement}

HP, TG, and KP initiated the project. TR, K.-HH, TG, KP, $\mathrm{TB}$, and HP developed and established the experimental design, HP and TR evaluated the data and wrote the manuscript. TR, TG, K.-HH, KP, and TB revised the manuscript.
Acknowledgements Open Access funding provided by Projekt DEAL. The authors wish to thank the German Science Foundation (Deutsche Forschungsgesellschaft) for funding the projects "Structure and dynamics of mixed-species stands of Scots pine and European beech compared with monospecific stands; analysis along an ecological gradient through Europe" (\# DFG PR 292/15-1) and "From near-death back to life: Mixed stands of spruce and beech under drought stress and stress recovery. From pattern to process (\# DFG PR 292/22-1). We would also like to thank the Bavarian State Ministry for Environment and Consumer Protection for funding the project "Pine (Pinus sylvestris) and beech (Fagus sylvatica) in mixed stands: suitable partners to ensure productivity on dry sites in times of climate change (KROOF II) (\# GZ: TKP01KPB-73853) and the Bavarian State Ministry for Nutrition, Agriculture, and Forestry for funding the project, W047 “ (\# GZ: 7831-28160-2018). We further thank the European Union for funding the project "Mixed species forest management. Lowering risk, increasing resilience (REFORM)" (\# 2816ERA02S, PCIN2017-026) under the framework of Sumforest ERA-NET, the Bayerische Staatsforsten (BaySF) for supporting the establishment of the plots and the Bavarian State Ministry for Nutrition, Agriculture, and Forestry for permanent support of the project W 07'Long-term experimental plots for forest growth and yield research " (\# 7831-22209-2013). Thanks also go to anonymous reviewers for their constructive criticism.

\section{Compliance with ethical standards}

Conflicts of interest The authors declare that they have no conflict of interest.

Open Access This article is licensed under a Creative Commons Attribution 4.0 International License, which permits use, sharing, adaptation, distribution and reproduction in any medium or format, as long as you give appropriate credit to the original author(s) and the source, provide a link to the Creative Commons licence, and indicate if changes were made. The images or other third party material in this article are included in the article's Creative Commons licence, unless indicated otherwise in a credit line to the material. If material is not included in the article's Creative Commons licence and your intended use is not permitted by statutory regulation or exceeds the permitted use, you will need to obtain permission directly from the copyright holder. To view a copy of this licence, visit http://creativecommons.org/licenses/by/4.0/.

\section{References}

Aasamaa K, Sõber A, Hartung W, Niinemets Ü (2004) Drought acclimation of two deciduous tree species of different layers in a temperate forest canopy. Trees 18(1):93-101

Allen CD, Breshears DD, McDowell NG (2015) On underestimation of global vulnerability to tree mortality and forest die-off from hotter drought in the Anthropocene. Ecosphere 6(8):1-55

Ammer C (2017) Unraveling the importance of inter- and intraspecific competition for the adaptation of forests to climate change. In: Cánovas FM, Lüttge U, Matyssek R (eds) Progress in Botany, vol 78. Springer, Heidelberg, pp 345-367

Ammer C (2019) Diversity and forest productivity in a changing climate. New Phytol 221(1):50-66

Ammer C, Albrecht H, Borchert H, Brosinger F, Dittmar C, Elling W, Kölling C (2005) Zur Zukunft der Buche (Fagus sylvatica L.) in Mitteleuropa. Kritische Anmerkungen zu einem Beitrag von Rennenberg et al. Allg Forst u J- Ztg 176(4):60

Arend M, Kuster T, GünthardtGoerg MS, Dobbertin M (2011) Provenance-specific growth responses to drought and air warming in 
three European oak species (Quercus robur, Q. petraea and $Q$. pubescens). Tree Phys 31(3):287-297

Assmann E, Franz F (1963) Vorläufige Fichten-Ertragstafel für Bayern. Forstl Forschungsanst München, Inst Ertragskd, p 104

Assmann E, Franz F (1965) Vorläufige Fichten-Ertragstafel für Bayern. Forstw Cbl 84(1):13-43

Atzmon N, Moshe Y, Schiller G (2004) Eco-physiological response to severe drought in Pinus halepensis Mill. trees of two provenances. Plant Ecol 171(1-2):15-22

Barbeta A, Penuelas J (2016) Sequence of plant responses to droughts of different timescales: lessons from holm oak (Quercus ilex) forests. Plant Ecol Divers 9:321-338

Bayerische Forstverwaltung (2015) Spätfrostschäden - erkennen und vermeiden. Merkblatt 31, LWF Freising, 3 pp

Bayerisches Staatsministerium für Ernährung (2001) Landwirtschaft und Forsten (2001) Die regionale natürliche Waldzusammensetzung Bayerns, LWF Bericht 32, Bayerische Staatsforstverwaltung, Bayer. Landesanstalt für Wald und Forstwirtschaft, Freising

Biermayer G, Tretter S (2016) Wie viel Fichte geht noch im Klimawandel. Vorschlag für eine Übergangsstrategie für Hochleistungsstandorte. LWF aktuell 1(2016):44-49

Bolte A, Ammer C, Löf M, Nabuurs GJ, Schall P, Spathelf P (2010) Adaptive forest management: a prerequisite for sustainable forestry in the face of climate change. Sustainable Forest Management in a Changing World. Springer, Dordrecht, pp 115-139

Bottero A, D'Amato AW, Palik BJ, Bradford JB, Fraver S, Battaglia MA, Asherin LA (2017) Density-dependent vulnerability of forest ecosystems to drought. J Appl Ecol 54(6):1605-1614

Brandl S, Falk W (2019) Mortalität von Fichte und Buche-Einfluss von Klima und Mischung. AFZ-Der Wald 2:10-13

Bréda N, Huc R, Granier A, Dreyer E (2006) Temperate forest trees and stands under severe drought: a review of eco-physiological responses, adaptation processes and long-term consequences. Annals For Sci 63(6):625-644

Ciais P, Reichstein M, Viovy N, Granier A, Ogée J, Allard V, Chevallier F (2005) Europe-wide reduction in primary productivity caused by the heat and drought in 2003. Nature 437(7058):529

D'Amato AW, Bradford JB, Fraver S, Palik BJ (2013) Effects of thinning on drought vulnerability and climate response in north temperate forest ecosystems. Ecol Appl 23(8):1735-1742

del Río M, Schütze G, Pretzsch H (2014) Temporal variation of competition and facilitation in mixed species forests in Central Europe. Plant Biol 16(1):166-176

Ewald J, Felbermeier B, von Gilsa H, Huss J, KenkG KC, Meyer P (2004) Zur Zukunft der Buche (Fagus sylvatica L.) in Mitteleuropa. Eur J For Res 123:45-51

Forrester DI (2014) The spatial and temporal dynamics of species interactions in mixed-species forests: from pattern to process. For Ecol Manage 312:282-292

Gebhardt T, Häberle KH, Matyssek R, Schulz C, Ammer C (2014) The more, the better? Water relations of Norway spruce stands after progressive thinning. Agr For Met 197:235-243

Göttlein A, Baumgarten M, Dieler J (2012) Site conditions and treeinternal nutrient partitioning in mature European beech and Norway spruce at the Kranzberger Forst. In: Matyssek R, Schnyder H, Osswald W, Ernst D, Munch JC, Pretzsch H (eds) Growth and Defence in Plants-Resource Allocation at Multiple Scales. Ecological Studies 220. Springer, Berlin, pp 193-211

Goisser M, Geppert U, Rötzer T, Paya A, Hube A, Kerner R, Bauerle T, Pretzsch H, Pritsch K, Häberle KH, Matyssek R, Grams TEE (2016) Does belowground interaction with Fagus sylvatica increase drought susceptibility of photosynthesis and stem growth in Picea abies? For Ecol Manage 375:268-278

Grossiord C (2018) Having the right neighbors: how tree species diversity modulates drought impacts on forests. New Phytol. https://doi. org/10.1111/nph.15667
Grossiord C, Granier A, Ratcliffe S, Bouriaud O, Bruelheide H, Chećko E, Scherer-Lorenzen M (2014) Tree diversity does not always improve resistance of forest ecosystems to drought. PNAS 111(41):14812-14815

Häberle KH, Weigt R, Nikolova PS, Reiter IM, Cermak J, Wieser G, Blaschke H, Rötzer T, Pretzsch H, Matyssek R (2012) Case Study "Kranzberger Forst": Growth and Defence in European Beech (Fagus sylvatica L.) and Norway Spruce (Picea abies (L.) Karst). In: R Matyssek et al. (eds.), Growth and Defence in Plants, Ecological Studies 220. Springer-Verlag Berlin, Heidelberg, pp 243-271 10.1007/978-3-642-30645-7_11

Häberle KH, Rötzer T, Pritsch K, Matyssek R (2015) Experimenteller Trockenstress in einem Buchen-Fichten-Mischbestand (KROOF). Mitteilungen der Deutschen Bodenkundlichen Gesellschaft Bd. 117: 202-206. Jahrestagung München Exkursionsführer 2015, Exkursion-Nr. E-02

Hanewinkel M (2001) Economic aspects of the transformation from even-aged pure stands of Norway spruce to uneven-aged mixed stands of Norway spruce and beech. For Ecol Manage 151(1-3):181-193

Hesse B, Goisser M, Hartmann H, Grams TEE (2019) Repeated summer drought delays sugar export from the leaf and impairs phloem transport in mature beech. Tree Physiol 3:192-200

Höwler K, Vor T, Seidel D, Annighöfer P, Ammer C (2019) Analyzing effects of intra-and interspecific competition on timber quality attributes of Fagus sylvatica L.-From quality assessments on standing trees to sawn boards. Eur J For Res 138(2):327-343

Kölling C, Knoke T, Schall P, Ammer C (2009) Überlegungen zum Risiko des Fichtenanbaus in Deutschland vor dem Hintergrund des Klimawandels. Forstarchiv 80(2):42-54

Lapenis A, Shvidenko A, Shepaschenko D, Nilsson S, Aiyyer A (2005) Acclimation of Russian forests to recent changes in climate. Glob Chang Biol 11(12):2090-2102

Leuschner C (2009) Die Trockenheitsempfindlichkeit der Rotbuche vor dem Hintergrund des prognostizierten Klimawandels. Jahrbuch der Akademie der Wissenschaften zu Göttingen: 281-296

Lévesque M, Saurer M, Siegwolf R, Eilmann B, Brang P, Bugmann H, Rigling A (2013) Drought response of five conifer species under contrasting water availability suggests high vulnerability of Norway spruce and European larch. Glob Chang Biol 19(10):3184-3199

Lloret F, Keeling EG, Sala A (2011) Components of tree resilience: effects of successive low-growth episodes in old ponderosa pine forests. Oikos 120(12):1909-1920

LWF (2017) http://www.lwf.bayern.de/boden-klima/umweltmonitorin g. Accessed July 2017

Lyr H, Fiedler HJ, Tranquillini W (1992) Physiologie und Ökologie der Gehölze. G Fischer Verlag, Jena

Meier IC, Leuschner C (2008) Belowground drought response of European beech: fine root biomass and carbon partitioning in 14 mature stands across a precipitation gradient. Glob Change Biol 14:2081-2095

Metz J, Annighöfer P, Schall P, Zimmermann J, Kahl T, Schulze ED, Ammer C (2016) Site-adapted admixed tree species reduce drought susceptibility of mature European beech. Glob Change Biol 22(2):903-920

Nickel UT, Weikl F, Kerner R, Schäfer C, Kallenbach C, Munch JC, Pritsch K (2018) Quantitative losses vs. qualitative stability of ectomycorrhizal community responses to 3 years of experimental summer drought in a beech-spruce forest. Global Change Biol 24(2): $5560-\mathrm{e} 576$

Niinemets Ü, Valladares F (2006) Tolerance to shade, drought, and waterlogging of temperate Northern Hemisphere trees and shrubs. Ecol Monographs 76(4):521-547 
Nikolova S, Raspe S, Andersen CP, Mainiero R, Blaschke H, Matyssek R, Häberle KH (2009) Effects of the extreme drought in 2003 on soil respiration in a mixed forest. Eur J For Res 128(2):87-98

Pinheiro J, Bates D, DebRoy S, Sarkar D, R Core Team _nlme (2017) Linear and nonlinear mixed effects models $\mathrm{R}$ package version 31-131. https://CRAN.R-project.org/package $=$ nlme\%3e

Pretzsch H, Bauerle T, Häberle KH, Matyssek R, Schütze G, Rötzer $\mathrm{T}$ (2016) Tree diameter growth after root trenching in a mature mixed stand of Norway spruce (Picea abies [L] Karst) and European beech (Fagus sylvatica [L]). Trees 30(5):1761-1773

Pretzsch H, del Río M, Ammer C, Avdagic A, Barbeito I, Bielak K, Brazaitis G, Coll L, Dirnberger G, Drössler L, Fabrika M, Forrester DI, Godvod K, Heym M, Hur V, Kurylyak V, Löf M, Lombardi F, Matović B, Mohren F, Motta R, den Ouden J, Pach M, Ponette Q, Schütze G, Schweig J, Skrzyszewski J, Sramek V, Sterba H, Stojanović D, Svoboda M, Vanhellemont M, Verheyen K, Wellhausen K, Zlatanov T, Bravo-Oviedo A (2015) Growth and yield of mixed versus pure stands of Scots pine (Pinus sylvestris $\mathrm{L}$.) and European beech (Fagus sylvatica $\mathrm{L}$.) analysed along a productivity gradient through Europe. Eur J For Res 134(5):927-947

Pretzsch H, Kahn M, Grote R (1998) Die Fichten-Buchen-Mischbestände des Sonderforschungsbereiches »Wachstum oder Parasitenabwehr? im Kranzberger Forst. Forstw Cbl 117(1):241-257

Pretzsch H, Rais A (2016) Wood quality in complex forests versus even-aged monocultures: review and perspectives. Wood Sci Technol 50(4):845-880

Pretzsch H, Schütze G, Uhl E (2013) Resistance of European tree species to drought stress in mixed versus pure forests: evidence of stress release by inter-specific facilitation. Plant Biol 15:483-495

Pretzsch H, Rötzer T, Matyssek R, Grams TEE, Häberle KH, Pritsch K, Kerner R, Munch JC (2014) Mixed Norway spruce (Picea abies [L.] Karst) and European beech (Fagus sylvatica [L.] stands under drought: from reaction pattern to mechanism. Trees 28(5):1305-1321

Pretzsch H, Schütze G, Biber P (2018) Drought can favour the growth of small in relation to tall trees in mature stands of Norway spruce and European beech. For Ecosyst 5(1):20

Pretzsch H, Schütze G, Uhl E (2012) Resistance of European tree species to drought stress in mixed versus pure forests: evidence of stress release by inter-specific facilitation. Plant Biol 15(3):483-495

Prodan M (1968a) Einzelbaum, Stichprobe und Versuchsfläche. Allg Forst u Jagdztg 139(10):239-248

Prodan M (1968b) Zur Gesetzmäßigkeit der Flächenverteilung von Bäumen. Allg Forst u Jagdztg 139:214-217

Quan C, Han S, Utescher T, Zhang C, Liu YS (2013) Validation of temperature-precipitation based aridity index: Paleoclimatic implications. Palaeogeogr Palaeoclimatol Palaeoecol 386:86-95

R Core Team (2018) R: A language and environment for statistical computing. R Foundation for Statistical Computing, Vienna, Austria https://www.R-project.org/

Reich PB, Sendall KM, Stefanski A, Wei X, Rich RL, Montgomery RA (2016) Boreal and temperate trees show strong acclimation of respiration to warming. Nature 531(7596):633

Rennenberg H, Seiler W, Matyssek R, Gessler A, Kreuzwieser J (2004) Die Buche (Fagus sylvatica L.)- ein Waldbaum ohne Zukunft im südlichen Mitteleuropa. Allg Forst u Jagdztg 175(10-11):210-224
Rodríguez-Calcerrada J, Pérez-Ramos IM, Ourcival JM, Limousin JM, Joffre R, Rambal S (2011) Is selective thinning an adequate practice for adapting Quercus ilex coppices to climate change? Ann For Sci 68(3):575

Rötzer T, Seifert T, Gayler S, Priesack E, Pretzsch H (2012) Effects of Stress and Defence Allocation on Tree Growth: Simulation Results at the Individual and Stand Level. In: Matyssek et al (eds) Growth and Defence in Plants: Resource Allocation at Multiple Scales. Ecological Studies 220. Springer-Verlag, Berlin, Heidelberg, 401-432

Rötzer T, Häberle KH, Kallenbach C, Matyssek R, Schütze G, Pretzsch $\mathrm{H}$ (2017a) Tree species and size drive water consumption of beech/spruce forests - a simulation study highlighting growth under water limitation. Plant Soil 418(1-2):337-356

Rötzer T, Biber P, Moser A, Schäfer C, Pretzsch H (2017b) Stem and root diameter growth of European beech and Norway spruce under extreme drought. For Ecol Manage 406:184-195

Schuldt et al (2016) How adaptable is the hydraulic system of European beech in the face of climate change-related precipitation reduction? New Phytol 210(2):443-458

Skatulla U (1989) Eine Methode zur erfolgreichen Bekämpfung der kleinen Fichtenblattwespe, Pristiphora abietina (Christ) (Hym, Tenthredinidae). Anzeiger für Schädlingskunde, Pflanzenschutz, Umweltschutz 62(8):156-157

Sohn JA, Saha S, Bauhus J (2016) Potential of forest thinning to mitigate drought stress: A meta-analysis. For Ecol Manage 380:261-273

Synek M, Janda P, Mikoláš M, Nagel TA, Schurman JS, Pettit JL, Brang P (2020) Contrasting patterns of natural mortality in primary Picea forests of the Carpathian Mountains. For Ecol Manage 457:117734

Tomasella M, Beikircher B, Haberle KH, Hesse B, Kallenbach C, Matyssek R, Mayr S (2018) Acclimation of branch and leaf hydraulics in adult Fagus sylvatica and Picea abies in a forest through-fall exclusion experiment. Tree Physiol 38:198-211

Trouvé R, Bontemps JD, Collet C, Seynave I, Lebourgeois F (2017) Radial growth resilience of sessile oak after drought is affected by site water status, stand density, and social status. Trees 31(2):517-529

Wagner S, Collet C, Madsen P, Nakashizuka T, Nyland RD, SaghebTalebi K (2010) Beech regeneration research: from ecological to silvicultural aspects. For Ecol Manage 259(11):2172-2182

Walentowski H, Kölling C, Ewald J (2007) Die Waldkiefer - bereit für den Klimawandel? LWF Wissen 57:37-46

Wermelinger B (2004) Ecology and management of the spruce bark beetle Ips typographus-a review of recent research. For Ecol Manage 202(1-3):67-82

Zang C, Pretzsch H, Rothe A (2012) Size-dependent responses to summer drought in Scots pine Norway spruce and common oak. Trees 26(2):557-569

Zang C, Rothe A, Weis W, Pretzsch H (2011) Zur Baumarteneignung bei Klimawandel: Ableitung der Trockenstress-Anfälligkeit wichtiger Waldbaumarten aus Jahrringbreiten. Environ Sci Policy 14:100-110

Publisher's Note Springer Nature remains neutral with regard to jurisdictional claims in published maps and institutional affiliations. 